\title{
Effect of light on the production of bioelectricity and added-value microalgae biomass in a Photosynthetic Alga Microbial Fuel Cell
}

\author{
Luísa Gouveia ${ }^{a}$, Carole Neves ${ }^{a}$, Diogo Sebastião ${ }^{a}$, Beatriz P. Nobre ${ }^{a, b}$, Cristina T. Matos ${ }^{a, *}$ \\ ${ }^{a}$ Laboratório Nacional de Energia e Geologia, I.P. Unidade de Bioenergia, Estrada do Paço do Lumiar, 1649-038 Lisboa, Portugal \\ ${ }^{\mathrm{b}}$ Instituto Superior Técnico, Centro Química Estrutural, DEQ Av. Rovisco Pais, 1, 1049-001 Lisboa, Portugal
}

\section{H I G H L I G H T S}

- Bioelectricity and value pigments production in a PAMFC.

- A light intensity increase resulted in a consequent increase of the PAMFC power.

- The maximum power produced was $62.7 \mathrm{~mW} / \mathrm{m}^{2}$ with a light intensity of $96 \mu \mathrm{E} /\left(\mathrm{m}^{2} \mathrm{~s}\right)$.

- Light intensity and PAMFC operation potentiated the carotenogenesis in the cathode.

\section{A R T I C L E I N F O}

\section{Article history:}

Received 21 September 2013

Received in revised form 6 December 2013

Accepted 11 December 2013

Available online 18 December 2013

\section{Keywords:}

Microbial fuel cell

Chlorella vulgaris

Pigments

Bioelectricity

\section{G R A P H I C A L A B S T R A C T}

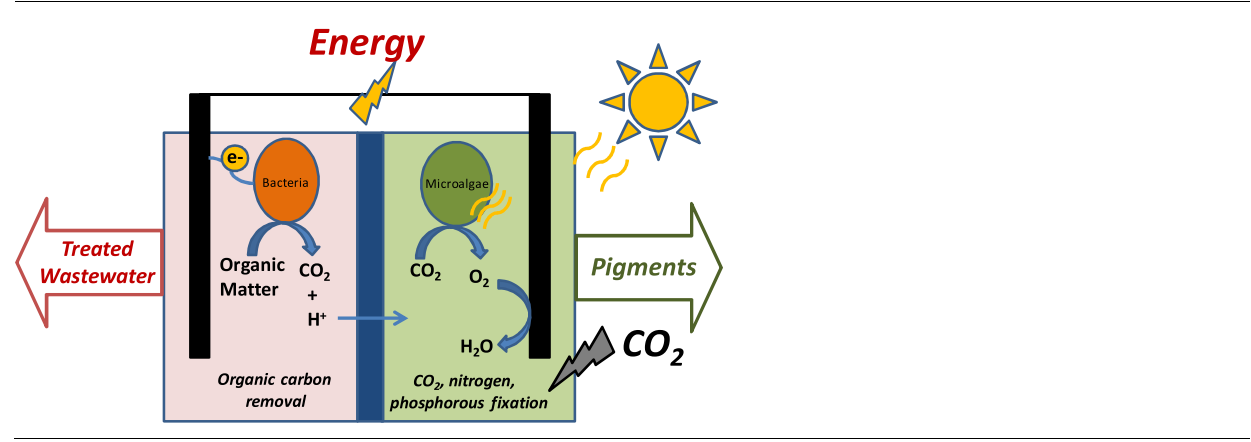

\begin{abstract}
A B S T R A C T
This study demonstrates the simultaneous production of bioelectricity and added-value pigments in a Photosynthetic Alga Microbial Fuel Cell (PAMFC). A PAMFC was operated using Chlorella vulgaris in the cathode compartment and a bacterial consortium in the anode. The system was studied at two different light intensities and the maximum power produced was $62.7 \mathrm{~mW} / \mathrm{m}^{2}$ with a light intensity of $96 \mu \mathrm{E} /$ $\left(\mathrm{m}^{2} \mathrm{~s}\right)$. The results showed that increasing light intensity from 26 to $96 \mu \mathrm{E} /\left(\mathrm{m}^{2} \mathrm{~s}\right)$ leads to an increase of about 6 -folds in the power produced. Additionally, the pigments produced by the microalga were analysed and the results showed that the light intensity and PAMFC operation potentiated the carotenogenesis in the cathode compartment.

The demonstrated possibility of producing added-value microalgae biomass in microbial fuel cell cathodes will increase the economic feasibility of these bioelectrochemical systems, allowing the development of energy efficient systems for wastewater treatment and carbon fixation.
\end{abstract}

(C) 2013 Elsevier Ltd. All rights reserved.

\section{Introduction}

The bioelectrochemical systems, such as microbial fuel cells (MFC) are able to convert the energy stored in any biodegradable substrate directly into electricity. The possibility of using light irradiation to potentiate the production of electricity in MFCs has received increased attention in the last decade, with the development of different systems and concepts capable of converting light into bioelectricity (Rosenbaum et al., 2010). These systems are

\footnotetext{
* Corresponding author. Tel.: +351217163636.

E-mail address: cristina.matos@lneg.pt (C.T. Matos).
}

commonly known as photo microbial fuel cells (PhotoMFCs) and could make use of the cost-free solar radiation to generate energy. Recently, several works proposed the use of photosynthetic microorganisms as biocatalysts, for oxidation and reduction reactions that occur in the anode and cathode compartments of a MFC. Rosenbaum et al. (2010) describes several PhotoMFCs systems. A few works report the use of photosynthetic bacteria for electron production in the anode compartment. Bacteria such as Rhodopseudomonas and other purple non-sulfur bacteria have been identified in anode biofilms (Xing et al., 2008). The use of microalgae in MFCs has also been reported both in the cathode and anode compartments. Raman and Lan (2012) described a system where green 